\title{
Pengaruh Penerapan Model Pembelajaran Think Pair Share terhadap Kemampuan Representasi Matematis ditinjau dari Kemampuan Awal Matematika Siswa
}

\author{
Indah Julia Sari ${ }^{1}$ dan Arnida Sari ${ }^{2}$. \\ Jurusan Pendidikan Matematika, Universitas Islam Negeri Sultan Syarif Kasim Riau \\ Jl. H. R. Soebrantas KM 15. 5, Pekanbaru, Indonesia. 29283 \\ e-mail: arnidasari@uin-suska. ac.id
}

\begin{abstract}
ABSTRAK: Penelitian ini bertujuan untuk mengetahui perbedaan kemampuan representasi matematis antara siswa yang mengikuti model pembelajaran Think Pair Share dengan siswa yang mengikuti model pembelajaran konvensional berdasarkan kemampuan awal matematika pada siswa kelas VIII SMP Negeri 22 Pekanbaru. Penelitian ini merupakan penelitian Quasi Eksperimen dan desain yang digunakan adalah Non-equivalent Posttest-Only Control Group Design. Populasi dalam penelitian ini adalah seluruh siswa kelas VIII SMP Negeri 22Pekanbaru. Sampel penelitian ini dipilih dengan menggunakan teknik cluster random sampling, terpilih kelas VIII. 1 sebagai kelas eksperimen yang diberikan model pembelajaran Think Pair Share, dan kelas VIII. 2 sebagai kelas kontrol yang diberikan model pembelajaran konvensional. Instrumen pengumpulan data yang digunakan adalah tes uraian untuk mengukur kemampuan representasi matematis siswa dan kemampuan awal matematika siswa. Teknik analisis data yang digunakan dalam penelitian ini adalah Uji-t dan anova dua arah. Berdasarkan hasil analisis data dapat disimpulkan bahwa: 1) Terdapat perbedaan kemampuan representasi matematis siswa yang mengikuti pembelajaran Think Pair Share dengan siswa yang menggunakan model pembelajaran konvensional; 2) Terdapat perbedaan kemampuan representasi matematis antara siswa dengan kemampuan awal matematika tinggi, sedang dan rendah, dan 3) Tidak terdapat pengaruh interaksi model pembelajaran dan kemampuan awal matematika terhadap kemampuan representasi matematis siswa.
\end{abstract}

Kata kunci: Think Pair Share, Kemampuan Representas Matematis, Kemampuan Awal Matematika,

\section{PENDAHULUAN}

Adapun tujuan yang diharapkan dalam pembelajaran matematika telah ditetapkan oleh NCTM (National Council of Teachers of Matematics). NCTM menetapkan lima standar kemampuan matematis yang harus dimiliki oleh siswa yaitu kemampuan pemecahan masalah, kemampuan komunikasi, kemampuan koneksi, kemampuan representasi dan penalaran dan pembuktian (National Council of Teachers of Mathematics, 2000). Salah satu kemampuan yang harus dimiliki siswa adalah kemampuan representasi. Kemampuan representasi merupakan dasar atau fondasi bagaimana seorang siswa dapat memahami dan menggunakan ide-ide matematika. Representasi berkaitan dengan dua hal, yaitu proses dan produk. Dengan kata lain, untuk mencerna/menangkap suatu konsep atau pengaitan dalam beberapa bentuk matematika (Dahlan, 2014). Representasi adalah bentuk interpretasi pemikiran siswa terhadap suatu masalah yang digunakan sebagai alat bantu untuk menemukan solusi dari masalah tersebut. Bentuk interpretasi siswa dapat berupa kata-kata atau verbal, tulisan, gambar, tabel, grafik, benda konkrit, simbol matematika dan lain-lain (Sabirin, 2014). Representasi matematis terdiri atas representasi visual, gambar, teks tertulis, persamaan atau ekspresi matematis (Lestari \& Yudhanegara, 2016)

Beberapa penelitian terkait dengan kemampuan representasi matematis telah dilakukan (Arnidha, 2016; Bagus, 2018; Kartini, 2009), tetapi berdasarkan laporan hasil The Third International 
Mathematics and Scienc Study (TIMSS) yang dikutip oleh Yudhanegara dan Lestari (2015), diketahui bahwa kemampuan siswa Sekolah Menengah Pertama di Indonesia dalam mempresentasikan ide atau konsep matematik dalam materi pembagian dan bilangan, aljabar, geometri, representasi data analisis dan peluang masih tergolong rendah.

Guru mata pelajaran matematika di SMP Negeri 22 Pekanbaru telah berusaha semaksimal mungkin meningkatkan kemampuan representasi matematis siswa. Namun usaha tersebut belum bisa mengatasi permasalahan lemahnya kemampuan representasi matematis siswa. Selain informasi yang diberikan guru, peneliti juga melakukan tes terhadap siswa kelas VIII. Soal yang diberikan sebanyak 3 butir soal yang dibuat berdasarkan indikator kemampuan representasi matematis siswa dan berkaitan dengan materi yang telah dipelajari siswa sebelumnya. Dari hasil tes diketahui bahwa kebanyakan siswa belum mampu mengerjakan soal yang diberikan. Hasil tes tersebut membuktikan bahwa kemampuan representasi matematis siswa masih rendah, yang menunjukkan bahwa $60 \%$ dari jawaban responden belum mampu mengungkapkan dan merepresentasikan ideide matematika ke dalam bentuk gambar, tabel dan diagram, 59\% jawaban responden belum bisa memberikan penjelasan dengan kata-kata atau teks tertulis dengan bahasan yang benar dan jelas serta mudah dipahami dan belum bisa membuat kesimpulan, dan $61 \%$ jawaban responden belum mampu merepresentasikan model matematika.

Terkait pemaparan fakta ini, maka tujuan dari pembelajaran matematika belum tercapai dengan baik. Maka diperlukan pembelajaran matematika yang dapat membuat siswa menjadi aktif dalam pembelajar matematika sehingga dapat meningkatkan kemampuan representasi matematika siswa menjadi lebih baik. Untuk itu diperlukan suatu model pembelajaran yang mampu mengembangkan pola pikir matematis dan melibatkan siswa secara langsung dan aktif.

Model-model pembelajaran yang dapat digunakan untuk meningkatkan kemampuan representasi matematis antara lain: problem-based learning (Noer \& Gunowibowo, 2018; Susilawati, Chandra, \& Abadyo, 2019), collaborative problem solving (Takaria \& Talakua, 2018) dan think pair share (TPS) (Arnidha, 2016). Model TPS ini juga terbukti mampu meningkatkan kemapuan komunikasi matematis (Abdi \& Hasanuddin, 2018; Wahyuni, Hendryawan, Nasrullah, \& Wachyar, 2018), kemampuan pemecahan masalah (Dwita, Bharata, \& Noer, 2018), dan hasil belajar matematika (Ardinata, Siswantoro, \& Suwarjo, 2018).

Model pembelajaran tipe TPS merupakan jenis pembelajaran yang hanya beranggotakan dua orang dan dirancang untuk bekerja secara individu serta bekerja sama dengan orang lain. Model ini memiliki prosedur yang ditetapkan secara eksplisit untuk memberi waktu lebih banyak pada siswa untuk berpikir, menjawab, dan saling membantu satu sama lain (Hamdayama, 2014). Dengan model pembelajaran ini, siswa lebih banyak memiliki kesempatan untuk berpartisipasi aktif, mengeluarkan ide-ide yang mereka miliki, sehingga siswa dapat memperoleh pemahaman yang lebih baik dan mampu memecahkan masalah terkait matematika.

Selain dari faktor model pembeljaran, faktor lain yang menentukan keberhasilan siswa yaitu Kemampuan Awal Matematika (KAM) yang merupakan kemampuan awal atau prasyarat awal untuk mengetahui adanya perubahan (Astuti, 2015). Kemampuan awal berkenaan dengan kecerdasan yang dimiliki oleh siswa. Bebicara tentang kecerdasan siswa, tingkat kecerdasan siswa beragam, ada yang pandai, sedang-sedang saja dan lemah. Hal ini didukung oleh Galton dalam Nufus dan Ariawan (2017) yang mengemukakan bahwa dari sekelompok siswa yang dipilih secara sebarang (tidak dipilih secara khusus), akan dijumpai siswa yang berkemampuan tinggi, sedang, dan rendah yang menyebar secara berdistribusi normal.

KAM penting untuk diketahui guru sebelum dimulai pembelajaran, karena dengan demikian dapat diketahui apakah siswa telah mempunyai pengetahuan yang merupakan prasayarat untuk mengikuti pembelajaran berikutnya, sejauh mana siswa telah mengetahui materi apa yang akan disajikan (Sumantri, 2015). Oleh karena itu, KAM disinyalir berperan sebagai moderator antara model pembelajaran dengan kemampuan representasi matematis. Beberapa peneltian yang 
menggali pengaruh KAM dalam hubungan antara model atau strategi dengan variabel terikat (Antika, Andriani, \& Revita, 2019; Mardaleni, Noviarni, \& Nurdin, 2018; Misrayanti \& Amir, 2019; Muhandaz, Lestari, \& Kurniati, 2018; Rahmayanti, Hasanuddin, \& Nelson, 2018).

KAM yang dimaksud di dalam penelitian ini adalah kemampuan awal peserta didik dari hasil nilai yang diperoleh peserta didik melalui tes sebelum peserta didik memasuki materi selanjutnya. Nilai tes yang diperoleh peserta didik juga dijadikan sebagai tolak ukur pembagian peserta didik berdasarkan kemampuan awal.

Jadi berdasarkan pemaparan tersebut dapat disimpulkan bahwa kemampuan awal diperlukan pada kemampuan representasi matematis siswa dalam penerapan pembelajaran Think Pair Share karena tingkat kemampuan awal siswa beragam, ada yang tinggi, sedang, dan rendah sebagaimana yang telah dikemukan oleh Galton. Berdasarkan uraian tersebut maka penulis tertarik untuk melakukan penelitian yang berjudul "Pengaruh Penerapan Model Pembelajaran Think Pair Share terhadap Kemampuan Representasi Matematis ditinjau dari Kemampuan Awal Matematika Siswa".

\section{METODE}

Populasi dalam penelitian ini adalah seluruh siswa SMP Negeri 22 Pekanbaru. Pemilihan sekolah ini berdasarkan pertimbangan permasalahan kemampuan representasi matematis siswa, sehingga dipandang sesuai sebagai tempat pelaksanaan penelitian. Penelitian dilakukan dikelas VIII karena pokok bahasan yang dijadikan bahan ajar dalam penelitian ini adalah materi kelas VIII semester 1, sehingga tidak mungkin mengambil populasi kelas VII dan IX. Pengambilan sampel selakukan secara "Sampling Purposive" yaitu teknik pengambilam sampel berdasarkan pertimbangan tertentu. Dari seluruh kelas VIII kemudian dipilih 2 kelas untuk dijadikan sampel penelitian. Dari dua kelas yang terambil, kelas VIII-1 dijadikan kelas kontrol dan kelas VIII-2 sebagai kelas eksperimen.

Berdasarkan permasalahan yang dikemukakan sebelumnya tujuan yang ingin dicapai, maka jenis penelitian ini adalah eksperimen semu (Quasi Ekesperimen). Desain yang digunakan dalam penelitian ini adalah Nonequivalent Posttest-Only Control Group Desaign. Pada desain ini terdapat dua kelompok yang dipilih secara langsung. kelompok pertama diberi perlakuan (X) dan kelompok yang lain tidak. Kelompok yang diberi perlakuan disebut kelompok eksperimen dan yang tidak diberi perlakuan disebut kelompok kontrol

Penelitian ini menggunakan dua cara pengumpulan data yaitu dengan tes soal berupa tes awal KAM dan tes akhir (post-test). Tes soal dilakukan sebelum dan sesudah pelaksanaan pembelajaran pada kelas eksperimen yang mendapat model pembelajaran Think Pair Share dan kelas kontrol dengan pembelajaran yang biasa diterapkan guru.

\section{HASIL DAN PEMBAHASAN}

\section{Hasil}

Sesuai dengan rumusan masalah penelitian, maka teknik yang digunakan dalam menganalisis data untuk menguji hipotesis 1 menggunakan uji-t, hipotesis 2 dan 3 menggunakan anova dua arah. Tujuan dari uji ini adalah untuk menyelidiki ada tidaknya perbedaan kemampuan representasi matematis antara siswa yang mengikuti model pembelajaran Think Pair Share dengan siswa yang mengikuti model pembelajaran yang diterapkan oleh guru berdasarkan pengetahuan awal tinggi, sedang dan rendah pada siswa. Prasyarat analisis data yaitu data berdistribusi normalitas dan homogenetas.

Sebelum penelitian menerapkan model pembelajaran Think Pair Share pada kelas eksperimen, lebih dahulu peneliti melakukkan test KAM terhadap dua kelas yang dipilih. Analisis data test ini menggunakan uji t, yang mana sebelum dilakukan uji t terlebih dahulu dilakukan uji prasayarat yaitu data berdistribusi normal dan homogen. 
Tabel 1. Hasil Uji Normalitas KAM

\begin{tabular}{cccc}
\hline Kelas & $\boldsymbol{X}^{2}$ hitung & \multicolumn{1}{c}{$\boldsymbol{X}_{\text {tabel }}^{2}$} & Kriteria \\
\hline Eksperimen & 2,87 & 11,07 & Normal \\
Kontrol & 7,67 & 11,07 & Normal \\
\hline
\end{tabular}

Tabel 2. Hasil Uji Homogenitas KAM

\begin{tabular}{ccc}
\hline \multirow{2}{*}{ Nilai Varians Sampel } & \multicolumn{2}{c}{ Kelas } \\
\cline { 2 - 3 } & Eksperimen & Kontrol \\
\hline S & 113,61 & 84,31 \\
N & 30 & 30 \\
\hline
\end{tabular}

Tabel 3. Hasil Uji- $t$ KAM

\begin{tabular}{cccc}
\hline $\boldsymbol{t}_{\boldsymbol{n}}$ & $\boldsymbol{t}_{\mathrm{t}_{\mathbf{1}}} \mathbf{5} \%$ & Keterangan \\
\hline 0,48 & 2,00 & $H_{\mathrm{u}}$ ditolak \\
\hline
\end{tabular}

Berdasarkan perhitungan dengan menggunakan uji-t diperoleh $t_{\text {hitung }}<t_{\text {tabeel }}$ taraf signifikan $5 \%$ atau 0,05, maka diperoleh $t_{t_{i}}=2,00$. Berdasarkan perhitungan, diketahui bahwa $t_{\text {nit }}<t_{t_{1}}$ yaitu $0,48<2,00$, sehingga dapat disimpulkan bahwa tidak terdapat perbedaan antara siswa kelas ekperimen dan kelas kontrol. Dengan kata lain, sebelum diberikannya perlakuan, yaitu penerapan model pembelajaran think pair share, kelas eksperimen dan kelas kontrol memiliki kemampuan representasi matematis yang sama.

Selanjutnya, dengan menggunakan data KAM, siswa dikelompokkan ke dalam salah satu dari tiga kategori, yaitu siswa dengan kemampuan awal tinggi, sedang, dan rendah. Setelah dilakukan perhitungan, kategori tingkat kemampuan awal matematika siswa kelas eksperimen dan kelas kontrol sebagai berikut:

Tabel 4. Kriteria Pengelompokan KAM

\begin{tabular}{cc}
\hline Kriteria & Kategori \\
\hline $\boldsymbol{x} \geq \mathbf{8}, \mathbf{1}$ & Tinggi \\
$\mathbf{6}, \mathbf{0}>\boldsymbol{x}>82,11$ & Sedang \\
$\boldsymbol{x} \leq \mathbf{6}, \mathbf{0}$ & Rendah
\end{tabular}

Oleh karena itu, berdasarkan kategori di atas, pengelompokkan siswa ke dalam salah satu dari tingkat kemampuan awal untukkelas eksperimen dan kelas kontrol disajikan pada tabel 5 berikut:

Tabel 5. Pengelompokan KAM Siswa

\begin{tabular}{cccc}
\hline KAM/Kelas & Tinggi & Sedang & Rendah \\
\hline Eksperimen & 8 siswa & 18 siswa & 4 siswa \\
Kontrol & 5 siswa & 20 siswa & 5 siswa \\
\hline
\end{tabular}

Berdasarkan tabel di atas, terlihat bahwa pada kedua kelas siswa lebih banyak terkategori pada tingkat KAM sedang. Hanya sebagian kecil yang berada pada tingkat KAM tinggi dan rendah.

Langkah selanjutnya yang peneliti lakukan adalah melaksanakan pembelajaran pada kelas eksperimen dan kelas kontrol. Setelah seluruh pertemuan selesai dilaksanakan, maka dilakukanlah posttest. Setelah diperoleh seluruh data posttest siswa, maka dilakukanlah serangkaian uji statistik inferensial untuk melihat pengaruh penerapan model pembelajaran terhadap kemampuan representasi matematis siswa. Adapun hasil perhitungan dapat dilihat pada tabel berikut: 
Tabel 6. Hasil Uji Normalitas Posttest

\begin{tabular}{cccc}
\hline Kelas & $\boldsymbol{X}^{2}$ hitung & \multicolumn{1}{c}{$\boldsymbol{X}_{\text {tabel }}$} & Kriteria \\
\hline Eksperimen & 8,32 & 11,07 & Normal \\
Kontrol & 4,62 & 11,07 & Normal \\
\hline
\end{tabular}

Tabel 7. Hasil Uji Homogenitas Posttest

\begin{tabular}{ccc}
\hline \multirow{2}{*}{ Nilai Varians Sampel } & \multicolumn{2}{c}{ Kelas } \\
\cline { 2 - 4 } & Eksperimen & Kontrol \\
\hline S & 57,66 & 46,43 \\
N & 30 & 30 \\
\hline
\end{tabular}

Tabel 8. Hasil Uji-t Posttest

\begin{tabular}{ccc}
\hline $\boldsymbol{t}_{\boldsymbol{n}}$ & $\boldsymbol{t}_{\mathbf{t}_{1}} \mathbf{5} \%$ & Keterangan \\
\hline 3,24 & 2,00 & $H_{\mathrm{u}}$ diterima \\
\hline
\end{tabular}

Berdasarkan perhitungan dengan menggunakan uji-t diperoleh $t_{\text {hitung }}>t_{\text {tabel }}$ dengan taraf signifikan 5\% diperoleh $t_{\text {tabel }}$ sebesar 2,0017 berarti perbandingan $t_{h}$ dengan $t_{t_{i}}$, adalah $3,24>2,00$ atau $t_{h} \geq t_{t_{i}}$, maka $H_{o}$ ditolak dan $H_{a}$ diterima. Artinya, terdapat pengaruh penerapan model pembelajaran think pair share terhadap kemampuan representasi matematis siswa.

Selanjutnya, untuk hipotesis kedua dan ketiga menggunakan rumus anova dua arah. Hasil perhitungan dapat dilihat pada Tabel 9 berikut.

Tabel 9. Hasil Uji Anova Dua Arah

\begin{tabular}{|c|c|c|c|c|c|}
\hline Sumber Variansi & Dk & JK & RK & Fh & $\mathbf{F k}$ \\
\hline Antar baris (Model) $\mathbf{A}$ & 1 & 564,27 & 564,28 & 12,62 & 4,02 \\
\hline Antar kolom (Kemampuan awal Matematika) B & 2 & 728,30 & 364,15 & 8,15 & 3,17 \\
\hline Interaksi Kemampuan awal Matematika*Model $(\mathbf{A} \times \mathbf{B})$ & 2 & $-19,60$ & $-9,80$ & $-0,22$ & 3,17 \\
\hline Dalam & 54 & 2414 & 44,70 & & \\
\hline Total & 59 & 3687 & - & & \\
\hline
\end{tabular}

Berdasarkan tabel hasil perhitungan uji anova dua arah di atas, maka dapat disimpulkan bahwa: 1) Antar baris $F(A)_{\text {nit }}=12,62$ dan $F(A)_{a_{1}}=4,02$ pada taraf signifikan $5 \%$, dengan kesimpulan $F(A)_{\text {nit }} \quad>F(A)_{t_{1}}$ yang berarti $H_{u}$ diterima dan $H_{0}$ ditolak. Artinya, terdapat pengaruh model pembelajaran think pair share terhadap kemampuan representasi matematis siswa. 2) Antar kolom. $F(B)_{\text {nit }}=8,15$ dan $F(B)_{t_{1}}=3,17$ pada taraf signifikan 5\%, dengan kesimpulan $F(B)_{\text {nit }} \quad>F(B)_{t_{1}} \quad$ yang berarti $H_{u}$ diterima dan $H_{0}$ ditolak. Maka dapat disimpulkan bahwa terdapat pengaruh kemampuan awal terhadap kemampuan representasi matematis siswa. Dan 3) Hasil analisis data untuk hipotesis ketiga dengan menggunakan anova dua arah menunjukan nilai $F(A \times B)_{\text {nit }}=-0,22$ dan $F(A \times B)_{t_{1}}=$ 3,17 pada taraf signifikan 5\%. Dengan kesimpulan $F(A \times B)_{\text {nit }} \quad<F(A \times B)_{t_{1}} \quad$ yang berarti $H_{0}$ diterima dan $H_{u}$ ditolak, sehingga dapat disimpulkan bahwa terdapat interaksi antara model pembelajaran dan kemampuan awal matematis terhadap kemampuan representasi matematis siswa. Oleh karena itu, dapat disimpulkan bahwa hasil penelitian ini menunjukkan adanya pengaruh penerapan model pembelajaran think pair share terhadap kemampuan representasi matematis ditinjau dari kemampuan awal matematika siswa.

\section{Pembahasan}

Sesuai dengan pemaparan pada hasil penelitian, maka dapat disimpulkan bahwa terdapat pengaruh penerapan model pembelajaran think pair share terhadap kemampuan representasi matematis berdasarkan kemampuan awal matematika siswa. Adanya pengaruh ini memperlihatkan bahwa 
model pembelajaran think pair share dapat dijadikan sebagai salah satu alternatif pembelajaran yang sesuai untuk memfasilitasi kemampuan representasi matematis siswa. Hal ini didukung oleh peningkatan aktivitas pembelajaran di kelas eksperimen.

Berdasarkan rata-rata persentase aktivitas pembelajaran matematika dengan menggunakan think pair share, dari lima pertemuan yang telah dilaksanakan menunjukkan bahwa rata-rata aktivitas pembelajaran mengalami kemajuan yang signifikan dari hari kehari. Sehingga dapat disimpulkan bahwa adalah model pembelajaran think pair share dapat diterima dengan baik oleh siswa dan siswa mampu mengikuti setiap langkah think pair share dengan baik. Peningkatan dari setiap pertemuan juga menandakan bahwa penerapan think pair share dari waktu ke waktu akan bisa mencapai nilai sempurna jika terus dilaksanakan dengan baik dan menerapkan setiap langkah think pair share sesuai dengan tujuan pembelajarannya.

Dengan demikian, kemajuan aktivitas pembelajaran disetiap pertemuan tentunya akan berdampak positif sebagai kemajuan kemampuan reprsentasi matematis siswa. Hal ini karena penerapan think pair share sendiri ditujukan untuk memberikan peluang dan peningkatan pada kemampuan representasi matematis siswa. Sehingga, melalui kemajuan representasi matematis siswalah nantinya think pair share dapat disimpulkan telah sesuai dan tepat digunakan dalam proses pembelajaran.

Selanjutnya, peneliti menyarankan beberapa hal sebagai berikut: 1) Untuk menerapkan pembelajaran dengan model pembelajaran think pair share, sebaiknya memperhatikan waktu yang telah direncanakan agar semua tahapan pada model pembelajaran dapat terlaksana dengan baik; 2) Diharapkan guru matematika untuk menjadikan model think pair share sebagai salah satu model pembelajaran yang dapat digunakan untuk meningkatkan kemampuan representasi matematis siswa; dan 3) Aspek yang ditinjau dalam penelitian ini adalah kemampuan Awal Matematika (KAM). Masih terbuka peluang bagi peneliti lain untuk bereksperimen pada berbagai aspek yang mempengaruhi hasil belajar siswa.

\section{REFERENSI}

Abdi, M., \& Hasanuddin, H. (2018). Pengaruh Model Pembelajaran Think Pair Share dan Motivasi Belajar terhadap Kemampuan Komunikasi Matematis Siswa Sekolah Menengah Pertama. JURING (Journal for Research in Mathematics Learning), 1(2), 99-110.

Antika, M. S., Andriani, L., \& Revita, R. (2019). Pengaruh Penerapan Model Pembelajaran Kooperatif Tipe Think-Pair-Square terhadap Kemampuan Pemahaman Konsep Matematis Ditinjau dari Kemampuan Awal Matematika Siswa SMP. JURING (Journal for Research in Mathematics Learning), 2(2), 118-129. https://doi.org/10.24014/juring.v2i2.7553

Ardinata, S., Siswantoro, S., \& Suwarjo, S. (2018). Pengaruh Model Pembelajaran Kooperatif Tipe Think Pair Share (TPS) terhadap Hasil Belajar Matematika Siswa. Jurnal Pedagogi, 7(3). Diambil dari http://jurnal.fkip.unila.ac.id/index.php/pgsd/article/view/15382

Arnidha, Y. (2016). Peningkatan Kemampuan Representasi Matematis melalui Model Pembelajaran Kooperatif Think Pair Share. JURNAL E-DuMath, 2(1). https://doi.org/10.26638/je.166.2064

Astuti, S. P. (2015). Pengaruh Kemampuan Awal dan Minat Belajar terhadap Prestasi Belajar Fisika. Formatif: Jurnal Ilmiah Pendidikan MIPA, 5(1). https://doi.org/10.30998/formatif.v5i1.167

Bagus, C. (2018). Analisis Kemampuan Representasi Matematis Siswa Dalam Menyelesaikan Soal Lingkaran Pada Kelas VII-B Mts Assyafi'iyah Gondang. Suska Journal of Mathematics Education, 4(2), 115-124.

Dahlan, J. A. (2014). Analisis Kurikulum Matematika. Dalam Kurikulum dan Pengembangannya (Vol. 1, hlm. 1-34). Diambil dari http://repository.ut.ac.id/4373/ 
Dwita, A., Bharata, H., \& Noer, S. H. (2018). Efektivitas Pembelajaran Think Pair Share Ditinjau dari Kemampuan Pemecahan Masalah Matematis Siswa. Jurnal Pendidikan Matematika Unila, 6(7). http://jurnal.fkip.unila.ac.id/index.php/MTK/article/view/17026

Hamdayama, J. (2014). Model dan metode pembelajaran kreatif dan berkarakter. Bogor: Ghalia Indonesia.

Kartini, K. (2009). Peranan Representasi dalam Pembelajaran Matematika. Seminar Nasional Matematika Dan Pendidikan Matematika 2009. Diambil dari http://www.uny.ac.id

Lestari, K. E., \& Yudhanegara, M. R. (2016). Penelitian pendidikan matematika. Bandung: PT. Refika Aditama.

Mardaleni, D., Noviarni, N., \& Nurdin, E. (2018). Efek Strategi Pembelajaran Scaffolding terhadap Kemampuan Pemecahan Masalah Matematis berdasarkan Kemampuan Awal Matematis Siswa. JURING (Journal for Research in Mathematics Learning), 1(3), 236-241. https://doi.org/10.24014/juring.v1i3.5668

Misrayanti, M., \& Amir, Z. (2019). Pengaruh Penerapan Model Pembelajaran Group Investigation terhadap Pemahaman Konsep Matematis Ditinjau dari Kemampuan Awal Matematis Siswa MTs. JURING (Journal for Research in Mathematics Learning), 1(3), 207-212. https://doi.org/10.24014/juring.v1i3.4761

Muhandaz, R., Lestari, M. M., \& Kurniati, A. (2018). Pengaruh Penerapan Pembelajaran Berbasis Masalah terhadap Kemampuan Pemecahan Masalah Ditinjau dari Kemampuan Awal Matematis Siswa SMP. JURING (Journal for Research in Mathematics Learning), 1(3), 260-267. https://doi.org/10.24014/juring.v1i3.7047

National Council of Teachers of Mathematics. (2000). Principles and Standards for School Mathematics: An Overview. National Council of Teachers of Mathematics.

Noer, S. H., \& Gunowibowo, P. (2018). Efektivitas Problem Based Learning Ditinjau dari Kemampuan Berpikir Kritis dan Representasi Matematis. JPPM (Jurnal Penelitian Dan Pembelajaran Matematika), 11(2). https://doi.org/10.30870/jppm.v11i2.3751

Nufus, H., \& Ariawan, R. (2017). Keterkaitan Hubungan Antara Kemampuan Komunikasi Dan Penalaran Matematis Siswa. Symmetry: Pasundan Journal of Research in Mathematics Learning and Education, 2(1), 29-42. https://doi.org/10.23969/symmetry.v2i1.240

Rahmayanti, K. R., Hasanuddin, H., \& Nelson, Z. (2018). Pengaruh Penerapan Metode Pembelajaran Aktif Modeling The Way terhadap Kemampuan Komunikasi Matematis Ditinjau dari Kemampuan Awal Siswa SMK Taruna Pekanbaru. JURING (Journal for Research in Mathematics Learning), 1(1), 65-70. https://doi.org/10.24014/juring.v1i1.4774

Sabirin, M. (2014). Representasi dalam Pembelajaran Matematika. Jurnal Pendidikan Matematika, 1(2), 33-44. https://doi.org/10.18592/jpm.v1i2.49

Sumantri, M. S. (2015). Strategi Pembelajaran Teori dan Praktik di Tingkat Pendidikan Dasar. Jakarta: Rajawali Pers.

Susilawati, S., Chandra, T. D., \& Abadyo, A. (2019). Kemampuan Representasi Matematis Siswa Kelas XI melalui Penerapan Model Problem Based Learning. Jurnal Pendidikan: Teori, Penelitian, Dan Pengembangan, 4(8). https://doi.org/10.17977/jptpp.v4i8.12402

Takaria, J., \& Talakua, M. (2018). Efektivitas Model Collaborative Problem Solving (CPS) Dalam Meningkatkan Kemampuan Representasi Matematis Mahasiswa Calon Guru Sekolah Dasar. Jurnal Pendidikan Sekolah Dasar (JPsd), 4(2), 190-203. https://doi.org/10.30870/jpsd.v4i2.3852

Wahyuni, E. T., Hendryawan, S., Nasrullah, A., \& Wachyar, T. Y. (2018). Meningkatkan Kemampuan Komunikasi Matematis Siswa SMP Melalui Pembelajaran Think Pair Share (TPS). Symmetry: Pasundan Journal of Research in Mathematics Learning and Education, 3(2), 125 136. https://doi.org/10.23969/symmetry.v3i2.1253 
Yudhanegara, M. R., \& Lestari, K. E. (2015). Meningkatkan kemampuan representasi beragam matematis siswa melalui pembelajaran berbasis masalah terbuka. Majalah Ilmiah Solusi, 1(04). 